\title{
THE CONTRIBUTION OF TECHNOPRENEURSHIP SCIENTIFIC LEARNING AND LEARNING READINESS \\ TOWARDS THE ENTREPRENEURSHIP LEARNING OUTCOMES IN HIGHER VOCATIONAL EDUCATION
}

\author{
Hendra Hidayat \\ Universitas Bung Hatta \\ Boy Yendra Tamin \\ Universitas Bung Hatta \\ Susi Herawati \\ Universitas Bung Hatta \\ Khairul \\ Universitas Bung Hatta \\ Eril Syahmaidi \\ Universitas Bung Hatta
}

\begin{abstract}
This research was motivated by the entrepreneurship learning outcomes in vocational education which is still poor. Technopreneurship scientific learning and learning readiness are assumed to be factors affecting entrepreneurship learning outcomes. The purpose of this study is to describe and test the contribution of technopreneurship scientific learning and readiness to learning of entrepreneurship learning outcomes. This research used the quantitative method with correlation descriptive. The population was all students who follow the general course of entrepreneurship in Higher Education for 1100 people. While the samples are 217 students who were selected by using proportional stratified random sampling. This research tool was a Likert scale and a valid and reliable reading comprehension test. Data were analyzed using descriptive statistics, simple regression and multiple regressions. The research findings show that there is a contribution of both technopreneurship scientific learning and learning readiness to entrepreneurship learning outcomes.
\end{abstract}

Keywords: technopreneurship scientific learning, learning readiness, entrepreneurship learning outcomes

Permalink: http://dx.doi.org/10.21831/jpv.v9i1.20466

Contact Hendra Hidayat hendrahidayat@bunghatta.ac.id Universitas Bung Hatta, Jl. Sumatera, Ulakkarang, Ulak Karang Utara, Padang Utara, Kota Padang, Sumatera Barat Indonesia 


\section{INTRODUCTION}

Nowadays, employment problems in Indonesia are faced with the inequality between job opportunity and labour supply. This gap has led to tight competition in getting jobs. Even college graduates, it is not easy to compete in getting a job. During the 2008-2009 periods, there has been an increase in the labour force of 2.26 million people, precisely increasing from 111.48 million people to 113.74 million people. This increase in labour supply is not entirely absorbed by the labour market; it results in an unemployment rate of $8.14 \%$ or 9.26 million people. From these 9.26 million unemployed, unemployed diplomas and graduates approximately are 1,260,000 people and 1,424,000 people (BPPT, 2010). Meanwhile, small and medium entrepreneurship (SMEs) as entrepreneurs are not fully able to absorb labour significantly. From the existing data, the number of entrepreneurs in Indonesia is still very small. It is only about $0.18 \%$ of the population.

While in America has reached 11\%, Singapore 7\%, Korea and Japan are above 5\%, European countries average is above $4 \%$, and India is almost 2\% (BPPT, 2010). Referring to the above conditions, the efforts to accelerate the growth of new businesses become very important, especially in response to the increasing supply of labour from year to year. One of the efforts to accelerate the growth of new businesses is to make breakthroughs through changing the mindset of college graduates from being as job seekers into work creators. Realizing this effort, universities have actually provided debriefing through entrepreneurship courses. However, its implementation is still more on the theory aspect. Even so, this can already be a very good capital base. Furthermore, the entrepreneurship material is just added to the technology skills, namely the ability to innovate through the application of technology. Technology-based entrepreneurship education, also known as technopreneurship, is an attempt to synergize between the theory and practice of various competencies in science related to technology and industry. Therefore, technology entrepreneurship education (technopreneurship) can be used as a learning process of a business atmosphere. Technopreneurship education in the future is very possible to be developed at universities in
Indonesia. However, in its development, universities are still facing various problems whether there is no policy or readiness from universities (teaching staff and educational infrastructure). This paper will describe the conditions of technopreneurship development and formulate models of technopreneurship development in universities

Various efforts should be made so that the function of vocational education as a media for the preparation of manpower can be realized. Among the efforts to improve the quality of education and learning to change the mindset of students related to work or livelihood. Most educational institutions in Indonesia currently only produce graduates who have the mindset as a job seeker and not as job creators. So the most important thing to do is to change the mindset of students about work or subsistence immediately to reduce unemployment in Indonesia. In addition to providing applied expertise, vocational educa-tion should also be able to give students the ability to create employment as workers. In addition, vocational students should have an interest in entrepreneurship. For this, the renewal of learning models that make students interested in entrepreneurship, creative and innovative must be conducted.

Almost all universities have entrepreneurship courses but not all of the college graduates are capable of entrepreneurship. In addition, graduates from college who graduated only rely on the diploma and competence of their respective fields to find work, but also did not get a decent job. If these conditions left ignored, the college will contribute to the increasing number of educated unemployment. Based on data from the Central Bureau of Statistics (BPS) on Unemployment Rate (TPT) of University graduates starting from February 2016, there are 7.02 million people or 5.5 percent, August 2016 are 7.03 million people or 5.61 percent, and last in February 2017 are 6.68 million people or 5.33 percent. It shows a modest rate of educated unemployment despite very little, but the intellectual unemployment rate for college graduates is very worrying.

Based on statistical data in February 2018, in Indonesia, there is 9.5 percent $(688,660$ people) of the total unemployed who are college graduates is no exception from graduates of vocational education. They hold a diploma three or strata one degree or bachelor 
degree. From that number, the highest number of unemployed, 495,143 people, is a university graduate with a bachelor degree. The educated unemployed (both diploma and strata 1) are increasing compared to 2013 with the percentage of unemployed college graduates of 8.36 percent $(619,288$ people) and 8.79 percent $(645,866)$ in 2012. This data describes that college graduates are still weak in the competition of the labour market; it is caused by, one of them, the learning process that occurs so far is still oriented to the output value.

Learning model becomes the main part in a learning process so it is very important to do a review in the form of needs analysis. If looking at the high unemployment rate among college graduates is no exception, higher education or vocational education certainly indicates the weakness of the learning process that occurred. There is no exception in the model of entrepreneurship learning. It is necessary to do the needs analysis. The direction of needs analysis of entrepreneurship learning model allows being integrated into entrepreneurship learning in higher education, in teaching and entrepreneurship learning so that learners can master the entrepreneurship material with the concept of learning by doing through the approach of production-based learning and technology. Needs analysis is a very important early stage in looking at the needs of a learning model that will be designed especially technopreneurship scientific learning model. Therefore, the purpose of this paper is to explore and explain the needs analysis of technopreneurship scientific learning model in higher vocational education.

\section{Review about Entrepreneurship Learning in Higher Education}

In achieving learning outcomes in vocational education, students will experience learning and the learning process (Hidayat \& Yuliana, 2018; Hidayat, Herawati, Hidayati, \& Syahmaidi, 2018; Hariyanto, Usman, \& Pardjono, 2017; Murtini, 2016). Learning is the process by which an individual undertakes to gain a new behavioural change, as a result of the individual's own experience in his interaction with his environment. Meanwhile, learning can be defined as a process that contains learning and self-transforming processes resulting from efforts in the process (Moeslichatoen, 2004). Furthermore, learning is a behavioural change through activity, practice, and experience. In learning, there are some basic components involved (Hamalik, 2003). From the opinion of the experts above, it can be concluded that learning is a process experiencing by an individual who keeps them from being uninformed to the knowing part and it involves the psychological elements of the individual.

In a simple lesson of entrepreneurship interpreted is how the transfer of knowledge and attitude changes as well as the right mindset about entrepreneurship. Entrepreneurship learning is an important concern because it is closely related to entrepreneurship theory, how to teach and entrepreneurship teaching strategies. Teaching entrepreneurship is the process of facilitating individuals with concepts and skills to be able to recognize business opportunities and have insight, confidence and ability to act (McIntyre \& Roche, 1999). Teaching entrepreneurship aims to inspire students, evoke emotions, and change mindsets (Al-Laham, Souitaris, \& Zerbinati, 2007; Lüthje \& Franke, 2003).

Besides, research on entrepreneurship theory has been studied by many experts such as decision theory (Busenitz \& Barney, 1997; Hitt \& Tyler, 1991) which helps us to understand why some entrepreneurs are able to see opportunities that are economically profitable while others are not. These theories are very helpful for students in facing problems in the field related to entrepreneurship issues. According to Ghoshal (2005), an effective way to teach entrepreneurship requires a combination of theory and application. Entrepreneurship education is defined as the delivery of entrepreneurial knowledge to students in terms of concepts, skills, and behaviours, followed by entrepreneurs (Pathak, 2003). In addition, of course, entrepreneurship learning stuff is supported by learning tools and entrepreneurship learning modules.

\section{Overview about Technopreneurship Scientific Learning Model}

Model is a conceptual framework that is arranged in a logical and systematic order as a guide in doing an activity. The learning model of scientific learning is a learning model to gain knowledge through two paths, namely the path of reason and the path of observation (Ibrahim, 2010). The operational form of the 
learning model of scientific learning is a scientific inquiry. This scientific inquiry is defined as a systematic attempt to get answers to problems or questions. Thus, the characteristic of learning model of scientific learning is the problem solving through reasoning and observation. Similarly, Majid (2014) revealed that learning activities can be matched by a scientific process. The model of scientific learning has an important role in developing attitudes, skills, and knowledge of students. In the process of learning which meets the scientific learning criteria, the scientists put forward inductive reasoning rather than deductive reasoning. Joyce \& Weil (2003) states that "the learning model is a plan or a pattern used as a guide in classroom planning or tutorial learning and to define learning tools such as books, films, tape recorders, computers, curriculum, etc". Furthermore, the application of Scientific Inquiry learning model in learning activities aims to improve students' process skills. Learning activities are done by experiment. Through experimental activities, students can try various ways to complete experiments conducted so as to develop the ability to think it.

Simply scientific technopreneurship means students are trained to actively engage in observing, trying, communicating and being able to produce products, with the resulting products containing technological elements in entrepreneurship. In addition, the students are facilitated to think creatively, analyze and able to produce products based on market and consumer needs (Ganefri, Hidayat, Kusumaningrum, \& Mardin, 2017; Hidayat, 2017a, 2017b, 2017c; Kusumaningrum, Hidayat, \& Ganefri, 2016). The scientific learning model of technopreneurship consists of (1) finding problems, needs analysis and learning analysis; (2) applying scientific technopreneurship cooperative approach; (3) designing a scientific technopreneurship business plan; (4) creating a product (prototype of goods or services); and (5) evaluating the work.

\section{Phase 1; Finding Problems, Needs Analysis and Learning Analysis}

Exploration of problems is important at first step. Learners can make observations as a group in the field, industry, community and also can discuss and obtain information from groups or people who need problems (Yulastri, \& Hidayat, 2017). Problems encountered can be found in a solution, including complex learning problems. The investigation for such solutions should be able to involve technological elements. Problems are identified and tested by alternative formulated solutions, and then it is the birth of the embryo and the early stages of the business. As the analysis of this requirement, it needs to be useful to provide usefulness to society. In addition, analysis of learning entrepreneurship in higher education, vocational and other public higher education were undertaken to look at the facilities, infrastructure, support references, and the readiness of the students in learning (Ganefri, Hidayat, Kusumaningrum, \& Mardin, 2017). Needs analysis in the community and learning curriculum is where to see the synchronization between students' competencies and competencies with technology elements so that the result of the solution is appropriate and beneficial (Hidayat, Herawati, Syahmaidi, Hidayati, \& Ardi, 2018).

\section{Phase 2; Scientific Technopreneurship Cooperative Approach}

After obtaining information on the problems and alternatives of the overview solution, the discussions were conducted in groups of 45 people. Group discussions are aimed at technopreneurship approaches that are seeking alternative solutions, technology-based business opportunities, but also from aspects of marketing, distribution and sales. It means that all business processes from up to bottom in integration opportunities and technology internalization should be considered. The scientific technopreneurship cooperative approach is not just a simple group discussion activity. In addition, this activity is also better to train highorder thinking skills.

\section{Phase 3; the Design of the Scientific Technopreneurship Business Plan}

At this stage, students are invited to design a business plan based on the problems found in the field and are trying to find new ideas and innovative solutions. The business plan is still designed as part of the Technopreneurship Scientific Learning Model. Students who design business plan follow the value of technology-based innovation. 


\section{Phase 4; Creating the Product (Goods and/or Services Prototype)}

In the form of prototypes of products and services designed, it must have been done. Products designed do not have to use high technology, but tend to have quality art. Thus, deep exploration and innovation need to produce innovations that have the highest potential of commercial value. The use of low technology with a touch of art and high beauty leads to different benefits and strengths.

\section{Phase 5; Evaluating of the Work}

Evaluation of the work is very important to look for the compatibility between what is done with the aim of workmanship. In addition, the evaluation work was carried out thoroughly to see the consistency of each stage, especially in generating Technopreneurship scientific business plans and products. Implementation of Technopreneurship Scientific Learning model in higher education towards the student gives the effect of the mindset of job seekers to job creators. Educators in the implementation of the Technopreneurship Scientific Learning model act as a facilitator, coordinator, mediator and motivator of learning activities for students. So, they are indirectly owned Entrepreneurship character, which includes unyielding, hard working and always innovating. The work produced by students and educators can be recorded. If the product has already passed the feasibility test, it is possible to obtain intellectual property rights. So as to produce a superior product and innovating entrepreneurs must go through in-depth surveys and observations of market conditions (Harms, 2015, Lackéus \& Middleton 2015; Tjahjono, Maryati, \& Fauziyah, 2015; Martín-Gutiérrez, Fabiani, Benesova, Meneses, \& Mora, 2015; Lee, Hallak, \& Sardeshmukh, 2016; Duval-Couetil, Shartrand, \& Reed, 2016, Kurniawan, 2017).

\section{Review of Learning Readiness}

Readiness is the overall condition of a person who makes it ready to respond in some way to a situation. According to Hergenhahn, \& Olson (2008) readiness is a prerequisite for subsequent learning. In contrast to the previous opinion of Hamalik (2003), readiness is the state of capacity existing in the student in relation to a specific teaching objective. Readiness can also be interpreted as a person's readi- ness or willingness to do something. An expert named Cronbach (2000) gives the meaning that readiness as a sense of all attributes or strengths that can make a person react in a certain way. While Bloom (2006) argues that learning readiness is a condition that has been prepared for an activity in learning. Then someone has been preparing all the needs associated with the learning. These needs can be physical needs and non-physical needs. Someone with the readiness of good physical conditions such as maintaining the condition of the body to stay healthy, adequate rest and others, then certainly in the process of learning, the person will have a good level of concentration in receiving learning materials provided so that it can stimulate the participation of people in the learning process.

Based on some opinions of the experts above, the authors conclude that readiness is the existence within a person that makes it ready to give answers or responses in achieving certain goals. In this research, understanding of readiness is a change of state in a person who makes it ready, able, and enough to do learning activities both in the sense of physical, psychological, and the material is ready so as to provide answers or responses to achieve learning objectives.

\section{RESEARCH METHODS}

This research used the quantitative method of a correlational descriptive type. The analysis technique uses simple regression and multiple regression which aims to test the contribution of two independent variables to one dependent variable. The instrument used was scale model Likert. The variables in this study consisted of three, namely: technopreneurship scientific learning (X1), learning readiness (X2), which is an independent vari-able and entrepreneurship learning outcomes $(\mathrm{Y})$ as the dependent variable.

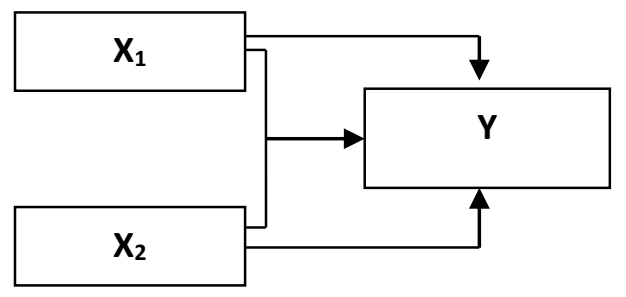

Figure 1. Framework of Relations between Independent Variables on the Dependent Variable 
The Population studying this study was students who take an entrepreneurship course in Higher Education in the number of 1100 people. As samples are 217 people. They were selected by using a proportional stratified random sampling technique

Main data collection instrument used in this study was in the form of documentation study on learning outcomes of entrepreneurship learning through technopreneurship scientific learning model and readiness to learn. The questionnaire was developed by researchers with a Likert scale model. The questionnaire consists of a number of statements formulated in the form of questions or statements with five alternative choices of answers in the form of attitude scales and frequency scales adapted to the purpose of the question or statement, i.e.: 1) Attitude Scale: strongly agree (SA), agree (A), disagree (DA), Slightly disagree (SD), and strongly disagree (SD); 2) Frequency scales: always (A), often (O), sometimes (ST), rarely $(\mathrm{RR})$, and never $(\mathrm{N})$. The use of attitude scales and scales frequency was tailored to the needs of each research variable. In accordance with the nature of the questionnaire, the weight of the statement items/positive questions were given the score 5, 4, 3, 2, and 1 . While the statement/negative question statement given weight $1,2,3,4$, and 5 .

Data Collection was conducted in Higher Education with the following procedures: (a) preparing technopreneurship scientific learning questionnaire and learning readiness; (b) provides an explanation of the instrument and how to fill it; (c) distribute the instruments and invite students to fill them out; (d) collect instruments according to plan.

Data were analyzed using descriptive statistics, simple and multiple regressions. Data analysis was assisted by using program SPSS version 22.00 .

follows:

The hypothesis of this study is as

H1 : Technopreneurship scientific learning contributes significantly to entrepreneurship learning outcomes

$\mathrm{H} 2$ : Learning readiness contributes significantly to entrepreneurship learning skills

$\mathrm{H} 3$ : technopreneurship scientific learning and learning readiness together contribute significantly to the entrepreneurship learning outcomes.

\section{RESULTS AND DISCUSSION}

Prior to the data analysis process, it needs to be tested for normality, linearity, and multicollinearity where the results are as follows.

Table 1. Normality Test

\begin{tabular}{|c|c|c|c|c|}
\hline No & Variable & $\begin{array}{l}\text { Sig. } \\
(P)\end{array}$ & $\begin{array}{l}\text { Sig. } \\
\text { alpha }\end{array}$ & Description \\
\hline 1 & $\begin{array}{l}\text { Entrepreneurs- } \\
\text { hip Learning } \\
\text { Outcomes(Y) }\end{array}$ & 0.181 & \multirow[t]{3}{*}{0.05} & Normal \\
\hline 2 & $\begin{array}{l}\text { Technopreneur- } \\
\text { ship scientific } \\
\text { learning }\left(X_{1}\right)\end{array}$ & 0.200 & & Normal \\
\hline 3 & $\begin{array}{l}\text { Readiness } \\
\text { Learning }\left(\mathrm{X}_{2}\right)\end{array}$ & 0.200 & & Normal \\
\hline
\end{tabular}

Normality test is done by using the method Kolmogorov-Smirnov. If Asymp. Sig. or $P$-value > of 0.05 (significance level), then the data is from a normally distributed population. The result of the normality test of data Asymp. Sig. of technopreneurship scientific learning value is 0.200 ; learning readiness is 0.200 , and entrepreneurship learning achievement is 0.181 . The three data means that the research variables are normally distributed.

Table 2. Linearity Test

\begin{tabular}{cccl}
\hline Variable & $\mathrm{F}$ & $\begin{array}{c}\text { level } \\
\text { significance }\end{array}$ & Conclusion \\
\hline $\mathrm{X}_{1} \mathrm{Y}$ & 9.575 & 0.009 & Linear \\
$\mathrm{X}_{2} \mathrm{Y}$ & 12.612 & 0.003 & Linear \\
\hline
\end{tabular}

Based on the data above, it is found that the relationship of technopreneurship scientific learning with entrepreneurship learning outcomes is linear. The relationship of learning readiness with entrepreneurship learning outcomes is also linear.

Table 3. Multicollinearity Test

\begin{tabular}{cccc}
\hline Variable & Tolerance & VIF & Description \\
\hline (Constant) & & & No \\
$\mathrm{X}_{1}$ & 0.820 & 1.219 & multicollinearity \\
$\mathrm{X}_{2}$ & 0.820 & 1.219 & \\
\hline
\end{tabular}

The next test is multicollinearity test. Based on multicollinearity test, score VIF of technopreneurship scientific learning is 1,219 and VIF of learning readiness value is 1.219 $<10$. Based on the result, it can be concluded that there is no multicollinearity between tech- 
nopreneurship scientific learning variables with learning readiness. The further results of the testing hypothesis can be seen in the following Table 4.

Table 4. Model Summary of the Effects of All Independent Variables on Dependent Variables

\begin{tabular}{ccccc}
\hline Model & R & $\begin{array}{c}\text { R } \\
\text { Square }\end{array}$ & $\begin{array}{c}\text { Adjusted } \\
\text { R Square }\end{array}$ & $\begin{array}{c}\text { Std. The error } \\
\text { of the Estimate }\end{array}$ \\
\hline 1 & $0520^{\mathrm{a}}$ & 0.270 & 0.249 & 14.409 \\
2 & $0502^{\mathrm{a}}$ & 0.252 & 0.231 & 14.587 \\
3 & $0.606^{\mathrm{a}}$ & 0.367 & 0.330 & 13.616 \\
\hline
\end{tabular}

Table 4 is a table to test the influence of technopreneurship scientific learning and learning readiness towards entrepreneurship learning outcomes. In the first model, the influence of technopreneurship scientific learning is to entrepreneurship learning outcomes. The R-Square value is the level of variation of the dependent variable, which can be predicted by the independent variable. The results of analyzing the data revealed that the Technopreneurship scientific learning affords $27 \%$ of entrepreneurship learning outcomes $\left(\mathrm{R}^{2}=\right.$ 0.270 ). In the second model, the analysis showed that the learning readiness is able to predict $25.2 \%$ of entrepreneurship learning outcome variables $\left(R^{2}=0.252\right)$. In the third model, the analysis showed that technopreneurship scientific learning and learning readiness together are able to predict $36.7 \%$ of students learning entrepreneurship outcome variables $\left(R^{2}=367\right)$.

Table 5. The Effect of Technopreneurship Scientific Learning on Entrepreneurship Outcomes

\begin{tabular}{lrrrrr}
\hline \multicolumn{6}{c}{ ANOVA $^{\mathbf{a}}$} \\
\hline Model & $\begin{array}{l}\text { Sum of } \\
\text { Squares }\end{array}$ & Df & \multicolumn{1}{c}{ Mean } & F & Sig. \\
& & Square & & \\
\hline Regression & 1067.127 & 1 & 1067.127 & 17.638 & $0.000^{\mathrm{a}}$ \\
1 Residual & 13068,071 & 216 & 60,500 & & \\
Total & 14135,197 & 217 & & & \\
\hline a. Dependent Variable: Y & & & \\
\hline \multicolumn{7}{l}{ b. Predictors: (Constant), X1 } \\
\hline
\end{tabular}

Table 5 shows the effect of scientific technopreneurship on entrepreneurship learning outcomes. The F-Count value is 17,638 while F-Table $=3.88$, which means F-Table is smaller than F-Count. Other information obtained in table 5 is a significance value $(0,000)$ below 0.05 . It can be interpreted that the variable of technopreneurship scientific learning influences the entrepreneurship learning outcomes variable.

Table 6. The Effect of Learning Readiness on Entrepreneurship Learning

Outcomes

\begin{tabular}{lccccc}
\hline \multicolumn{6}{c}{ ANOVA $^{\text {a }}$} \\
\hline Model & $\begin{array}{l}\text { Sum of } \\
\text { Squares }\end{array}$ & df & $\begin{array}{c}\text { Mean } \\
\text { Square }\end{array}$ & F & Sig. \\
\hline Regression & 1017.169 & 1 & 1017.169 & 16.749 & $.000^{\text {a }}$ \\
Residual & 13118.028 & 216 & 60.732 & & \\
Total & 14135.197 & 217 & & & \\
\hline a. Dependent Variable: Y & & & \\
\hline b. Predictors: (Constant), X2 \\
\hline
\end{tabular}

Table 6 shows the effect of learning readiness on entrepreneurship learning outcomes. The F-Count value was obtained 16,749 while F-Table $=3.88$, which means that F-Table is smaller than F-Count. Other information obtained in table 5 is a significance value $(0,000)$ below 0.05 . It can be interpreted that learning readiness variables influence the entrepreneurship learning outcomes variable.

Table 7. The Effect of Technopreneurship Scientific Learning and learning readiness on Entrepreneurship Learning Outcomes

\begin{tabular}{|c|c|c|c|c|c|}
\hline \multicolumn{6}{|c|}{ ANOVA $^{a}$} \\
\hline Model & $\begin{array}{l}\text { Sum of } \\
\text { Squares }\end{array}$ & $\mathrm{df}$ & $\begin{array}{l}\text { Mean } \\
\text { Square }\end{array}$ & $\mathrm{F}$ & Sig. \\
\hline Regression & 1557.943 & 2 & 778.972 & 13.316 & $.000^{\mathrm{a}}$ \\
\hline Residual & 12577.254 & 215 & 58.499 & & \\
\hline Total & 14135.197 & 217 & & & \\
\hline \multicolumn{6}{|c|}{ a. Dependent Variable: $\mathrm{Y}$} \\
\hline \multicolumn{6}{|c|}{ b. Predictors: (Constant), X2, X1 } \\
\hline
\end{tabular}

Table 7 shows the effect of technopreneurship scientific learning and learning readiness to entrepreneurship learning outcomes. The F-Count value was obtained 16,749 while F-Table $=3.88$, which means that F-Table is smaller than F-Count. Other information obtained in table 5 is a significance value $(0,000)$ below 0.05 . It can be interpreted that learning readiness variables influence the entrepreneurship learning outcomes variable. 


\section{Discussion}

Technopreneurship scientific learning and Its Contribution to Entrepreneurship Learning Outcomes

Results Regression test show that technopreneurship scientific learning contributes $27 \%$ to entrepreneurship learning outcomes. Significance also shows that technopreneurship scientific learning contributes to entrepreneurship learning outcomes. The activity of students perform activities to find problems, needs analysis, and analysis of learning predicted to improve learning entrepreneurship outcomes. Technopreneurship scientific learning helps students organize or monitor cognitive, planned thinking, deliberate, goal-directed, and future-oriented mental processing that can be used to complete learning tasks that lead to learning outcomes (Okedeyi, Oginni, Adegorite, \& Saibu, 2015). In addition, technopreneurship scientific learning can be used as a method in achieving a goal of learning outcomes (Nst \& Sahyar, 2017). Technopreneurship scientific learning is a procedure that helps students to understand and find problems and find solutions to these problems (Daryanto, 2013). The scientific approach makes learning more active and less boring. Students can construct their knowledge and skills through the facts found in field investigations for learning. In addition, with this scientific-based learning approach, students are encouraged to be more capable of observing, asking, reasoning, and communicating or presenting the things learned from natural phenomena or direct experience. In entrepreneurship learning, for example, students can be invited to see the events, observing events, phenomena, context or situation related to the product, the type of business, so that students always remember it in the learning process. Students who are able to conduct an experiment are predicted to be able to improve academic achievement (Sadler, Foulk, \& Friedrichsen, 2017). Furthermore, effective Technopreneurship scientific learning will produce good learning outcomes and can improve the quality of someone's learning (Hosnan, 2014; Rein, 2017).

Based on a previous exposure, it can be concluded that scientific learning in vocational higher education able to predict whether or not the student entrepreneurship learning outcomes. Students in knowing and understanding various materials using a scientific approach realize that information can come from anywhere, anytime, does not depend on the direction of information from the lecturer. Therefore, the expected learning conditions created are directed to encourage students to find out from various sources through observation, and not just be informed.

Learning Readiness and its Contribution towards Entrepreneurship Learning Outcomes

Based on the data analysis, it can be seen that on average the overall readiness of students is also in the low category. It means that the readiness of students still needs to be improved. The result of data analysis shows that readiness study able to predict $25,2 \%$ variable of entrepreneurship learning outcomes. The role of learning readiness toward entrepreneurship learning outcomes is a positive linear role. It means high readiness followed by high student entrepreneurship learning outcomes. Thus, students who have a high learning readiness will have high entrepreneurship learning outcomes. This is in line with the opinion of Slameto (2010) which states that the learning readiness affects student entrepreneurship learning outcomes. In the process of learning, it is needed self-preparation to deal with it. Learning is someone's way of learning something that cannot be done yet. A new person can learn something when they have had "Readiness" to learn something (Kagan, 1990; Cronbach, 2000; Muijs \& Reynolds, 2001; Lally, 2010; Abu Taleb, 2013; Buldu \& Er, 2016). In fact, each individual has individual differences, and then each individual has different developmental backgrounds (Bloom, 2006). This causes the pattern of formation of readiness which is also different within each individual. Similarly, readiness in learning is very influential on the personal development of a person to maturity in learning so that someone will be easy and ready to receive something that will be learned in learning itself (Kurniabudi, Rohayani, \& Sharipuddin, 2015). In addition, a similar study of learning readiness was conducted by Spearman (2010) where the study assessed the attitudes, abilities and behaviours of a learner toward taking responsibility for the learning of the learner. The result, students who have high learning readiness will be able to follow the learning well and be able to develop the skills they have. Based 
on the above explanation, it can be concluded that a healthy physical condition, good mental (emotional), learning needs that support the learning process and learning objectives can run well where readiness affects the learning outcomes. If student learning outcomes are not achieved well, then the learning goal also cannot be achieved well anyway.

\section{The contribution of Technopreneurship Sci- entific learning and Learning Readiness to- wards Entrepreneurship Learning Outcomes}

The research results showed that technopreneurship scientific learning and learning readiness together contribute significantly to entrepreneurship learning outcomes. This finding is obtained based on the series of data analysis that the regression coefficient of 0.606 . The coefficient of determination ( $\mathrm{R}$ Square) technopreneurship scientific learning and learning readiness towards students' entrepreneurship learning outcome is equal to 0.367 . That It means the contribution of both Technopreneurship scientific learning variables and learning readiness towards the student entrepreneurship learning achievement is $36.7 \%$, while the rest $(100 \%-36.7 \%=63.3 \%)$ is explained by other variables which are not examined in this study. As the Nst \& Sahyar (2017) study, it shows that the use of technopreneurship scientific learning and can improve learning outcomes. The results of this study revealed that technopreneurship scientific learning and learning readiness together can be a factor that affects the student entrepreneurship learning outcomes. The use of technopreneurship scientific learning will have an impact on the well-being of students, in this case, is in the form of learning outcomes. This means that the scientific strategy used in learning will affect the learning outcomes obtained by students in vocational education (Mohadab, Bouikhalene, \& Safi, 2018). Readiness is the initial condition for students who are ready in doing a learning activity both in the sense of physically, psychology, and the material experienced by the students themselves and able to respond to all actions in the learning process in the classroom so that the learning objectives are achieved. Students who have good learning readiness will tend to be trained to do something if they are given exercises about what has been learned. If they are trained to use scientific-learning strategies technopreneurship that have been taught then they will likely influence their learning outcomes.

\section{CONCLUSIONS}

Based on the findings and discussion of the results of research, it can be concluded as follows: (1) technopreneurship scientific learning contributes significantly to entrepreneurship learning outcomes. It means technopreneurship scientific learning has significance towards entrepreneurship learning outcomes; (2) learning readiness contributes significantly to entrepreneurship learning outcomes. It means learning readiness has significance towards entrepreneurship learning outcomes; (3) the technopreneurship scientific learning and learning readiness together contribute significantly to entrepreneurship learning outcomes. It means technopreneurship scientific learning and learning readiness have a significance towards entrepreneurship learning outcomes. It can be said that the high level of entrepreneurship learning outcomes is not only influenced by one variable only (technopreneurship scientific learning and readiness to learn) but also influenced together by technopreneurship scientific learning and readiness to learn.

Furthermore, based on the results of this research, it is suggested to lecturers, students and higher vocational education to be able to use scientific learning entrepreneurship. In addition, for researchers can be a reference and development of advanced research.

\section{REFERENCES}

Abu Taleb, T. F. (2013). Necessary school readiness skills for kindergarten success according to Jordanian teachers. Early Child Development and Care, 183(12), 1878-1890.

Al-Laham, A., Souitaris, A., \& Zerbinati, S. (2007). Do entrepreneurship programmes raise the entrepreneurial intention of science and engineering students? The effect of learning, inspiration and resources. Journal of Business Venturing, 22(4), 566.

Bloom, B. S. (2006). Taxonomy of Educational Objectives: The Classification of Educational Goals. London: David McKay Company, Inc. 
BPPT. (2010). Naskah Akademis Kebijakan Pengembangan Technopreneurship. Mimeo, Pusat Pengkajian Kebijakan Peningkatan Daya Saing, Jakarta.

Buldu, M., \& Er, S. (2016). School readiness and school entry-age: views and experiences of Turkish teachers and families on a new educational policy. Education and Science, 41(187), 97-114.

Busenitz, L.W., \& Barney, J. B. (1997). Differences between entrepreneurs andmanagers in large organizations: Biases and heuristics in strategic decision-making. Journal of Business Venturing, (12):1:9-30.

Central Bureau of Statistics. (2016). Statistics News: Labor Indonesia in August 2016. Status No. 103/11 / Th.XIX, November 7, 2016.

Central Bureau of Statistics. (2017). Statistics News: Labor Indonesia in February 2017. Status No. 47/05 / Th.XX, May 5, 2017.

Central Bureau of Statistics. (2018). Statistics News: Labor Indonesia in February 2018. Status No. 42/05 / Th.XXI, May 7, 2018.

Cronbach, L. J. (2000). Essentials of Psychological Testing. New York: Harper \& Row Publisher.

Daryanto. (2013). Pendekatan Pembelajaran Saintifik Kurikulum 2013. Jakarta: Gava Media.

Duval-Couetil, N., Shartrand, A., \& Reed, T. (2016). The Role of Entrepreneurship Program Models and Experiential Activities on Engineering Student Outcomes. Advances in Engineering Education, 5, 1.

Ganefri, Hidayat, H., Kusumaningrum, I., \& Mardin, A. (2017). Needs Analysis ofEntrepreneurships Pedagogy of Technology and Vocational Education with Production Base Learning Approach in Higher Education. International Journal on Advanced Science, Engineering and Information Technology, 7(5), 1701-1707. http://dx.doi.org/10.18517/ijaseit.7.5.151 0
Ghoshal, S. (2005). Bad Management Theories Are Destroying Good Management Practices. Academy of Management Learning \& Education, 4(1), 75-91.

Hamalik, O. (2003). Perencanaan Pengajaran Berdasarkan Pendekatan Sistem. Jakarta: Bumi Aksara.

Harms, R. (2015). Self-regulated learning, team learning and project performance in entrepreneurship education: Learning in a lean startup environment. Technological Forecasting and Social Change, 100, 21-28.

Hariyanto, V. L., Usman, H., \& Pardjono, P. (2017). The implementation of integrated learning for developing the entrepreneurship readiness for the students of vocational high school majoring in architecture engineering. Jurnal Pendidikan Vokasi, 7(2), 228241.

Hergenhahn, B. R., \& Olson, M. H. (2008). Theories of Learning. Jakarta: Kencana Prenada Media Grup.

Hidayat, H. (2017a). How to Implement Technology Science for Entrepreneurship by Using ProductBased Learning Approach and Participatory Action Learning System in Higher Education?. Advanced Science Letters, 23(11), 10918-10921. https://doi.org/10.1166/asl.2017.10186

Hidayat, H. (2017b). Impact of Learning with the Production-Based Learning Model in Vocational School. International Journal of Research in Engineering and Social Sciences, 7(2), 1-6. http://indusedu.org/pdfs/IJRESS/IJRESS _1057_92032.pdf

Hidayat, H. (2017c). How is the Application and Design of a Product-Based Entrepreneurship Learning Tools in Vocational Higher Education?. Advances in Social Science, Education and Humanities Research, volume 102, 223 228. http://dx.doi.org/10.2991/ictvt17.2017.38.

Hidayat, H., Herawati, S., Hidayati, A., \& Syahmaidi, E. (2018). Pembelajaran 
Kewirausahaan Dengan Pendekatan Berbasis Produksi Sebagai Alternatif Mempersiapkan Lulusan Berkualitas Di Pendidikan Tinggi. In Prosiding Seminar Nasional Pakar (pp. 123-129). http://trijurnal.lemlit.trisakti.ac.id/index. php/pakar/article/download/2709/2339

Hidayat, H., \& Yuliana. (2018). The Influence of Entrepreneurship Education and Family Background on Students' Entrepreneurial Interest in Nutritious Traditional Food Start Ups in Indonesia. International Journal of Engineering and Technology(UAE), 7(4), 118-122. https://doi.org/10.14419/ijet.v7i4.9.2063 1

Hidayat, H., Herawati, S., Syahmaidi, E., Hidayati, A., \& Ardi, Z. (2018). Designing of technopreneurship scientific learning framework in vocational-based higher education in Indonesia. International Journal of Engineering and Technology(UAE), 7(4), 123-127. https://doi.org/10.14419/ijet.v7i4.9.2063 2

Hitt, M.A., \& Tyler, B. B. (1991). Strategic decision models: Integrating different perspectives. Strategic Management Journal, 12(5):327-352.

Hosnan. (2014). Pendekatan Saintifik dan Kontekstual. Jakarta: Ghalia Indonesia.

Ibrahim, M. (2010). Dasar-dasar Proses Belajar Mengajar. Surabaya: Unesa University Press.

Joyce, B, \& Weil, M. (2003). Model of Teaching (Fifth-Edition). New Delhi: Prentice-Hall of India Private Limited

Kagan, S. L. (1990). Readiness 2000: Rethinking rhetoric and responsibility. Phi Delta Kappan, 72(4), 272-279.

Kurniabudi, Rohayani, H, \&, Sharipuddin. (2015). Readiness Factors for measuring e-Learning Readiness in Higher Education. International Conference on Computer Science and Computational Intelligence.

https://doi.org/10.1016/j.procs.2015.07.5 64.

Kurniawan, R. (2017). The Influence of
Application of Learning Model Teaching Factory 6 Step (TF-6M) and Achievement of Learning entrepreneurship to Entrepreneurship Interest. An innovation of Vocational Technology Education, 10.

Kusumaningrum, I., Hidayat, H., Ganefri, Anori, S. \& Dewy, M.S. (2016). Learning Outcomes in Vocational Education: a Business Plan Development by Production-Based Learning Model Approach. International Journal of Environmental and Science Education, 11(18), 11917-11930. https://files.eric.ed.gov/fulltext/EJ11225 58.pdf

Lally, J. R. (2010). School readiness begins in infancy. Phi Delta Kappan, 92(3), 1721.

Lee, C., Hallak, R., \& Sardeshmukh, S. R. (2016). Innovation, entrepreneurship, and restaurant performance: A higherorder structural models. Tourism Management, 53, 215-228.

Lackéus, M., \& Middleton, K. W. (2015). Venture creation programs: bridging entrepreneurship education and technology transfer. Education + Training, 57: 48-73.

Lüthje, C., \& Franke, N. (2003). The 'making' of an entrepreneur: Testing models of Entrepreneurship intent among engineering students at MIT. $R \& D$ Management, 33, 135-147.

Majid, Al. (2014). Pembelajaran Tematik Terpadu. Bandung: PT Remaja Rosdakarya

Martín-Gutiérrez, J., Fabiani, P., Benesova, W., Meneses, MD, and Mora, CE. (2015). Augmented reality to promote collaborative and autonomous learning in higher education. Computers in Human Behavior, 51, 752-761.

McIntyre, J. R., \& Roche, M. (1999). University education for entrepreneurs in the United States: A critical and retrospective analysis of trends in the 1990s (Working Paper Series 99/00021). Atlanta: Georgia Institute of Technology, Center for International 
Business Education \& Research.

Moeslichatoen, R. (2004). Metode

Pengajaran Di Taman Kanak - Kanak. Jakarta: PT Asdi Mahasatya.

Mohadab, M. E., Bouikhalene, B., \& Safi, S. (2018). Applied Computing and Informatics Predicting rank for scientific research papers using supervised learning. Applied Computing and Informatics. https://doi.org/10.1016/j.aci.2018.02.002

Muijs, D., \& Reynolds, D. (2001). Effective

Teaching, Evidence and Practice. London: Paul Chapman Publishing

Murtini, W. (2016). Implementasi model "GEPPRAK" dalam pembelajaran kewirausahaan untuk meningkatkan minat berwirausaha di sekolah menengah kejuruan. Jurnal Pendidikan Vokasi, 6(3), 335-345.

Nst, F. H., \& Sahyar. (2017). The Effect of Scientific Inquiry Learning Model Based on Conceptual Change on Physics Cognitive Competence and Science Process Skill (SPS) of Students at Senior High School. Journal of Education \& Practice. 8 (5), 120-126.

Okedeyi, A., Oginni, A. D., Adegorite, S. O., $\&$ Saibu, S. (2015). The Relevance Of Multi-Media Skills In Teaching And Learning Of Scientific Concepts In Secondary Schools In Lagos State, Nigeria. Journal of Education \& Practice. 6 (15), 150-155.

Pathak, R. D. (2003). Creativity, Innovation and Entrepreneurialism: the New Public Management Tools to Combat Inequality and Exclusion in the 21 st century. Paper presented at the Public Administration: Challenges of Inequality and Exclusion.

Rein, V. (2017). Towards the Compatibility of Professional and Scientific Learning Outcomes : Insights and Options in the Context of Competence Orientation, 4(4), 325-345. https://doi.org/10.13152/IJRVET.4.4.2.

Sadler, T. D., Foulk, J. A., \& Friedrichsen, P. J. (2017). Evolution of a Model for Socio-Scientific Issue Teaching and Learning To cite this article: SocioScientific Issue Teaching and Learning. https://doi.org/10.18404/ijemst.55999.

Slameto, B. (2010). Belajar dan Faktor-faktor yang mempengaruhi. Jakarta: Rineka Cipta

Spearman, L. R (2010). Self-Directed Learning Readiness in Clinical Laboratory Scientists: Developing Skill for Practice. Disertasi. Texas: Texas Tech University.

Tjahjono, H. K., Maryati, T., \& Fauziyah, F. (2015). Yogyakarta Student Entrepreneurship Intention Information Technology (IT). Journal of Business Strategy, 17, 17-27.

Yulastri, A., \& Hidayat, H. (2017). Developing an Entrepreneurship Module by Using Product-Based Learning Approach in Vocational Education. International Journal of Environmental and Science Education, 12(5), 1097 1109. https://files.eric.ed.gov/fulltext/EJ11455 87.pdf. 